\title{
NBSIR 73-159 \\ U.S. Membership in the International Organization of Legal Metrology
}

Thomas M. Stabler

Office of Engineering and

Information Processing Standards

National Bureau of Standards

Washington, D. C. 20234

April 1973

Southwestern Gas Measurement Short Course

University of Oklahoma Center

for Continuing Education

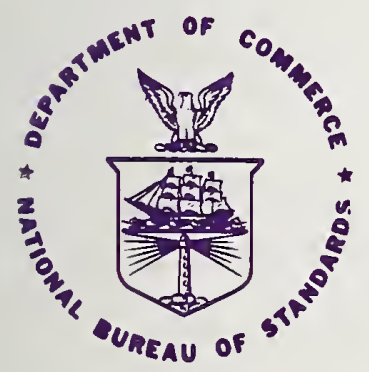

U. S. DEPARTMENT OF COMMERCE

NATIONAL BUREAU OF STANDARDS 


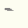


NBSIR 73-159

\section{U.S. MEMBERSHIP IN THE INTERNATIONAL ORGANIZATION OF LEGAL METROLOGY}

Thomas M. Stabler

Office of Engineering and Information Processing Standards National Bureau of Standards

Washington, D. C. 20234

April 1973

Southwestern Gas Measurement Short Course University of Oklahoma Center for Continuing Education 



\title{
U.S. MEMBERSHID IN THE \\ INTERNATIONAL ORGANIZATION OF LEGAL METROLOGY
}

\author{
Themas M. Statler \\ National Bureau of Standards \\ Washington, D. C. 20234
}

\section{DACKGROUIE}

The Internetical Organization of Legal Metrology (CIIC) was fourded in 1955 tc promote intergovernmental cccperation in the :ielc of legal metrology, which, broally, relates to the compatibility of standards of measurement and the legislation and Government regulations which may affect such standards of measurement. Aside from its activities as $a$ center of documentation and information exchange in legal metrology, the OIML most importantly recomends uniform international requirements for measuring instruments and works out model laws and regulations for consideration by member states.

The subject of membership in this Organization had been under discussion and consideration since OIML wos formed in 1955. We did not join at that time since it was the position of the United States that internationel technical crganizations such as this should be established within the framework of the United Nations. Today, however, in view of the increasing importance of international trade and the effect of OII progrems on such trade, U.S. membership was deemed a vital necessity.

On April 11, 1972, President Iixon requested the Senate to Give its advice end consent to accession to the Convention establishirs the OIML (Tab 1 ). In his letter to the Senate recommending accession he said:

"The U.S. bas in the past been an interested observer in the Organization's work, and I believe that accession to the Convention would now be of clear advantage to the United States. As the world's largest trading nation and as a world leacer in the stendards field, we would be better able to assume a positive role in the setting of international stendards ior measurement and in so doing, to expand our international trade."

This request provided for U.S. membership in OIML, and it was the intenticn of the Executive Branch that the Department of Comerce would ke assiened feneral respocsibility for program implementation and direction. Within Commerce, the National Eureay of Standards would be responsible for the Jevelopment of U.S. pceitions for technical matters arisire in the OIML. The Department of State would retuir. cooriinating and tucgetary responsibilities and, in collaboration with Commerce, would designate U.S. representatives to meetirgs of the OIML.

WHAT IS THE INTERNATIONAL ORGANIZATION OF LEGAI MATEOLCGY?

OIML is actually the "legal" counterpart of the International Conference of Weights and Measures (CIPM), In which the U.S. has been an active member since its inception in 1875. Legal questions were almost always on the agenda of the CIPM, and at one point, consideration was given to establishing within the scope of the CIPM a "Consultative Committee of Practical Metrology." If this had happened the U.S. would have been a participant in the normal course of decision-making on the legal aspects of metrology. That was not the course of events, however, and the OIML was formed and the U.S. still had no influence in this major sector of international standards activity. In fact, it was difficult as a non-member, even to keep informed of OIML's activities.

Following is a brief description of the functions and organization of OIML. Metrology, of course, is the science of measurement -- development of standards, instruments, and measurement procedures. It becomes legal metrology when the measurements are related to the official enforcement of laws, as in the enforcement of weights and measures laws in the marketplaces of our own country. The main interest of OIML is in standards for instruments and measurement techniques involved in the legal determination of quantity and quality.

Public authorities have the obligation to ensure that legal measurements within a country be put on a uniform basis. The national regulations which are developed for this purpose have for many years been developed within a country independent of similar work ir other countries. Consequently, national laws and specifications often differ widely. Today, with rapidly developing and changing technology, and with the rapid expansior. of international trade, these differences pose a potential impediment to international trade.

OIML now has 38 member nations ( $T a b 2$ ). Its headquarters staff is small -- only seven people at present. Its estimated 1972 budget is approximately $\$ 109,000$, an increase from $\$ 88,000$ 1. 1972 .

OIML's primary functions are:

to form a cinter of decumentation and incor- 

mation in the field of legal metrology,

to establish ciose relations with national weights and reasires officials,

to furnish adviscry assistance to interested states,

to determine the gereral principles of legal Ietrology,

to issue uniform international recommendations respecting legal requirements for use and control of measuring instruments,

to establish a code of specifications and tolerarces with which measuring instruments must comply in order to acquire international approval,

to establish and promulgate model laws and regulations in the field of legal metrology.

The decisions of the Organization are promulgated as recommendations; they do not have the force of law. However, members of the Orgarization are "morally obliged to implement these decisions as far as possible."

Organizationally, OIML consists of: (Tab 3)

(1) the Interrationa' Conference of Legal Metrology, which is composed of delegates from member states and which meets at least every 6 years. Decisions of the conference are submitted to member states "for information, consideration, and recomendation";

'(2) the Internationai Comittee of Legal Metrology (CIML), which consists of ore delegate from each state, and which meets every 2 years. The technical work of OIML is conducted by working groups within the framework of the committee.

(3) the International Bureau of Legal Metrology (BIML), which constitutes the Secretariat for the Organization.

Forty-two specific standards have already been recommended to the ir.ternational community by OIMI (Tab 4). A careful review of these recommendations is sufficient to demonstrate that many products currently manufactured in the United States may be denied access, either conditionally or absolutely, to the markets of foreign rations which ultimately adopt the OIN standards as a basis for their dor.estic law.

The potential adverse nature of the existing recommendations takes many forms. Illustrative of these are: (a) a requirement that product or pattern approval be obtained before the item can be marketed in the country in question.

(b) specific design requirements that eliminete U.S. forms in censtruction.

(c) a provision that a product may be tested for up to 2 years to assure it maintains its performance.

Turning to the broeder question of procucts which might conceivably be affected by orgoing activities within working groups of the OIML, an analysis suegests that exports valued in excess of $\$ 400$ rillion, or about one-half of our 1971 exports of instruments and controls, may ultimately be embraced by decisions of the Organization.

\section{OIML'S RELATIONSHIP TO DEVELOPING COUNTRIES}

The OIML is currently moving into the area of metrology standards for the developing countries. A questionnaire has been submitted to these countries in order to determine their particular needs in metrology and to find out what technical and administrative advice the OIML might offer in setting up "Departments of Legal Metrology."

The implications of this OIML program in the field of international trade should not be overlooked. It is a long-term program and, as an OIML member, the United States can provide technical assistance in the adoption of laws, regulations, and metrological practices by the developing nations.

\section{INTERNATIONAL TRADE POLICIES}

Government agencies responsible for U.S. international trade policies are currently very concerned with non-tariff trade barriers, which impede the flow of trade between countries. The U.S. and other governments in the General Agreement on Tariffs and Trade (GATT) have mounted a major effort to eliminate these barriers to free trade. Additionally, the Western European countries, as a part of their economic integration efforts, have begun a program of harmonization of their standards and the implementation of certificatica schemes, on a regional rather than on a global basis. This regional system has the effect of reducing or eliminating certain U.S. products from the European Market. The U.S. efforts in GATT, hofefully, will result in a "Code of Conduct" in standards that will eliminate adverse effects of harmonization and certification in U.S. exports.

The GATT discussions have clearly revealed that non-tariff barriers have been generated by the decisions made in the OIML. Therefore, U.S. membership ir. OIN should so hand in hard with the GAm initiatives. 

The primayy purzcse of U.S. memoerstip in OI:T is ecororid. We nust improve our activity in many fields of internaticnal standaraization to ensire that cur techuical expertige is reflected in internaticnsl starduris, ari that our products cen rove ireely in $\forall$ orld trade. Scientit”c consiceraticrs alone wculd justify rerkership in OI:I, but the deterioratinE J.Z. balance-ofpayments situation is of overriding importance.

For wany years, following World War II, the U.S. ran substantial surpluses to help offset some of the deficits in other parts of our balance-ofpayments schedule. During the past five years, bowever, our trade surpius has declined from $\$ 7$ billion in 1964 to a total trade deficit of $\$ 2$ billion in 1071. Father than restricting imports, the U.S. has taken the positive approach of trying to increase exports. One such positive step has been to strengthen U.S. participation in internationei standards activities and is the subject of leqislation presently before Congress, the International Voluntary Standards Cooperation Act of 1973. By Joining the OIML we have added another positive step in the field of international standardization.

Because it has not been a member until recently, the U.S. has had no influence on OIML actions. An analysis of some of the OIMI decisions, (on clinical thermometers, gas meters, meters for fluids, taximeters, and weighing machines) by the Nationa? Eureal of Standards, by U.S. firms concerned witr the ranufacturing of these products, and by the Bureau of Domestic Commerce of the Department cf Commerce, shows clearly that there are adverse effects on U.S. business from the setting of standards by an organization without U.S. participation. The effects lisually are not intended, but do in fact result from the lack of U.S. input during the time when the standard is being developed.

The potential impact of the OIML has generally gone unrecognized within the domestic private sector of member nations simpiy because they do not encourage industry participation. OIML membership is offjcially constituted sciely by government representatives of the 38 member nations. It has passed 42 model reculations of which an appreciable number are the basis for recent and future Eurciean Common l'arket Directives. These directives will carry the full force of national law following ratification by the ten member nations.

Unfortunately, the provisions of certain OIML liodel laws are basei on rather narrow experience. This is not recessariy the fault of the conorbitire crficials, it reflects the experience of the partiziparts in nandling trade matters of significance to ther.selves. Therefore from one point of view, they may constrain trade, a trend which has become apparent to the oil industry, for example.

In view of possible revisions to the General igreerert on Fariff and Trade, inere is even greater ircentive for shared fe эral and industrial urderstanding with resard to the OMML. Frankly, the private sector must sclicit federal action if domestic industry is to be both a sound competitor and remain in compliance with proposed GATT provisions, including the possible Code of Conduct which defines the documentation issued by OIML as mandatory standards.

IMPACT ON THE OIL INDUSTRY ${ }^{l}$.

"American Petroleum Institute (API) voluntary standards do not specify tolerances or error limits for a measurement process, or demand pattern approval or regulate any mechanical specification which in any way could hinder competition among manufacturers of such equipment. Such decisions have traditionally been the prerogative of local, state or federal authorities both here and abroad. This charge certainly belongs to the legal metrology or weights and measures specialists whenever the consuming public is involved.

"On the other hand, API has had an overriding concern that OIMI mandatory standards or model regulations if made applicable to international petroleum commerce, might adversely affect the type of equipment best suited to measure large volumes of crude oil and products. For example, very large and sophisticated measuring stations, often packed with electronic equipment, are used to measure ofl from a ship or pipeline to a refinery. In the United States only the contracting parties are normally concerned with the selection of equipment used. So long as the equipment operates within acceptable limits of error, there is no restriction as to its specifications or makeup.

"In Europe especially, added value taxes are assessed at many intermediate measurement points; the total tax on gasoline exceeds 50 cents per gallon as compared to a domestic naximum of 14-15 cents. However, current OIML model reculations are often indiscriminate. They are applicable to virtually every device used in large and small applications because of tax application.

"One OIML Model Regulation, entitled "Meters for Liquids Other Than Water," written by Working Group Fl. 7 has recently been made a Common Narket Directive. This mandatory standard precludes the use of meters in some commercial apoliastions ard prevents the use of some American instruments $=-0 .-$ rectly. It does this for two reascns. First, through various provisions it very drastice:? limits the size of the instrument, and seconi, it effectively outlaws the use of associated electronic equipment. 
"It should be se?"-evident that netroleum operations are thereicre restrained from applying already froven tecknoloey, and similar U.S. suppliers cannot congete with their full line of products. This burdens the baiarce of pajments, even today,

"The next ten years should see the OIM model regulations implemented by merber countries. In that same feriod, U.S. oil imports vill have grown somewhere between 50 and 58 percent of demand, according to ccmpetent authorities. Shortly after 1980, the drain to the U.S. balance of payments is projected to be 17 billion dollars per year, from oil imports alone.

"Some estimate that by potential exclusion of the most advanced oil measurement apparatus from producing countries, the U.S. will be spending 85 million dollars per year for oil purchased but never received due to equipment degradation. Additionaliy, foreign affiliates in other countries, notably those imposing an added-value tax, will contribute a similar dollar loss because of the payment of excessive taxes on imprecisely measured bulk quantities of oil.

"The oil industry believes the most effective way to minimize this loss of approximately 200 million dollars ennually, including equipment excluded, is to have knowledgeable U.S. officials participate in OIML deliberations.

Many U.S. industries face these and similar problems relating to measurements in international trade."

\section{COORDINATION WITI OTHER STANDARDS ORGANIZATIONS}

The OIML is primarily concerned with the setting up of standards (performance criteria, design, and use of weights and measures devices) used in commerce and industry. The International Bureau of Weights and Measures (BIPM) on the other hand provides for international cocperation in matters relating to primary standards and units of measurement; for example, meter, kilogram, second, ampere, kelvin, mole, and candela. There is also a difference between the work done by the OIML and the International Organization for Stendardization (ISO). The ISO is a nongovernmental organization which prepares and prcmuleates voluntary standards agreed to by incustry. The OIML in comparison attempts to harmonize model draft laws for weights and measures which will be adopted by states as law of the land.

1. Statement by Vallace N. Seward, Assistant to the Senior Vice Fresident, Industry Affairs, AFI, before the Senate Comittee on Foreign Relations, A.ug. 2, 1072 .
OIML coordinates its standards recommendations and activities with the folloving organizations: Internationel Bureau of Weights and Measures, International Organization for Standardization, International Electrotechrical Commission, Internaticnel Union of the Gas Industry, International Commission for Uniform Method of Sugar Analysis, International Association of Cereal Chemistry, International Bottling Center, International Office of Wine, Customs Cocperation Council, Internationel Union of Pure and Applied Chemistry, Internationel Union of Pure and Applied Physics, European Committee of Weighing Instrument Builders, European Committee of Builders of Oil Meters.

OIM maintains administrative and technical liaison with the U.N. Economic and Social Council, the U.N. Economic Comission for Europe, the U.N. Economic Commission for Asia, UNESCO, the U.N. Organization for Industrial Development, OECD, EED, COMECON, and the International Measurement Conference (United Kingdom).

OIML also maintains liaison with about 25 commercial and/or standards organizations in European countries.

\section{UNITED STATES PARTICIFATION}

The U.S. became an official member of OIML October 22, 1972, with the National Bureau of Standards being assigned general responsibility for the development of U.S. positions for technical matters arising in the OMML.

The Fourth International Conference of OIML was held October 23-28, 1972. Delegates from 34 nations convened in London for discussions that were designed to result in uniform laws and regulations, practices and procedures in international legal metrology. The Conference dealt principelly with the following agenda topics, for which U.S. position papers were prepared:

(1) Relations with International Standards Organizations.

(2) Long Term Work Policy of the Organization.

(3) Proposed International Recommendations.

(4) Assistance to Developing Countries.

(5) Standard Reference Materials.

(6) Performance vs. Design Specifications.

Named to the U.S. Delegation were:

Delegation Head, Dr. Lawrence M. Kushner, Acting Director, National Bureau of Standarcis ( Tab 5); 
William E. Andrus, Jr., Prcgram Manager, Engineering and Information Frocessing Standards, Naticnal Eureau of Etandards;

Wallace N. Seward, fissistart to the Senior Vice Fresidert, imerican Petroleum Institute;

Walter M. Young, President, Howe Pichardson Scale Corpary; ar.

Dr. Alan G. Mencher, Scientific Attache, U.S. Embassy in London.

Thomas M. Stabler, Special Assistant for Internationel Programs, National Bureau of Standards, accompanied the delegation as an ISO/OIML representative. Mr. Andrus was designated by the Department of State to serve as the U.S. member of the International Comittee (CINI), and was invited by the CII President to serve on the Presidential Council.

Twenty-three Project Recommendations were adopted as OIMI International Recomendations (Tab 3).

\section{SUMMARY}

In summary, the benefits to the United States of participation in OIML are:

to improve opportunities for exporting measurement instruments and help our balance-of-payments position;

to obtain better information regarding measurement techniques in the field;

to influence internationally adopted measurement techniques so U.S. procedures will not be put at a disadvantege;

to insure that the United States can influence the adoption by developing countries of model laws and uniform procedures in order to avoid having the United States put at a disadvantage visa-vis European and other courtries; and

to facilitate the development of an international standards program for the United States in this area.

"The main purpose of OI:ML" is to establish the necessary minimum technical requirements which measuring instruments have to possess in order for them to be approved by member states and for them to be recommended for interrational use.

"The international documents have been prepared by a method which is custorary in the CI:I and which coes not differ essentially from the methods used by other orgarizations, such as the ISO and IEC.

"The riethod provides a guarartee that the final documents represent the best possible compromise which one can expect, bearing in mind the origiral strongly divergent opinions. It does not guarantee thet all the cour.tries corcerned, not even those which belong to the workirg sroups, will be in complete agreement with the final text. However, generally speaking, merbers of the working groufs are ready to accect comcrcmise solutions. Tho major factors are constantly borne in mind, vis., (1) the measuring instruments which are manufactured on the basis of the specifications to be drawn uo must guarartee a reasonable certainty of accurate measurements in normal use, and (2) the interests of the industry producing the measuring instruments.

"The first factor requires no explanation. As regards the second, it is obviously in the interests of the manufacturers to find $a$ market, as large us possible, for a unified product. The ideal situation from OINI's point of view, therefore, would be that a ranufacturer who constructs a type cf measuring instrument in one country should be able to export it to any other country with the certainty that it will satisfy the legal regulations of that country.

"To this end it is necessary that the merber countries should implement the decisions of OIML by incorporating them in their national legislation. As you know, the treaty which set up the OIML imposes a moral obligation on the member countries to do this, and then only "as much as possible." The treaty cannot go further than this, but of course it is hoped that as many member courtries as possible will honor this moral obligation.

"It is thus not of great importance whether the recomendations are adopted in their entirety or only partially. In the present circumstances, it would be a considerable advance if their basic premises were accepted.

"The ideal was to make possible the mutual acceptance of type approval and perhaps even of the verification of single instruments by ail weights and measures administrations in the world.

"Naturally, this ideal will have to be regularly adapted to new ideas.

"Yet whatever adjustments social progress will demand of us, the ideal will continue to point the way to the future.

"We shall still have many obstacles to face on this road. The language problem springs imediately to mind, and many believe that OIML will seriously

2. Address by A. J. van Male (Netherlazds), Fresident, CIMI, to the 1970 ivational Conference or Weights and Neasures. 
- 
heve to consider in the near future the pcssibility of usins Inglish as an satitiongl oreratiorel larguage. It is not difficult to think of a number of other cbstacles hich may affect the issuc. All of us, and I rear ever; ccuntry in the world, rave, after all, hal sefarate end aifferent ristcries in metrclo:y. Put we have a comon purpose. Let us, therefore, strive for a common Iuture in legal metrolog."

$\underline{T A B} 1$
LETTER OF TRAISMITTAI

The White House, April 11, 1972.

To the Senate of the United States:

Today I ask the Senate to give its advice and consent to accession by the United States to the Convention Establishing an Internationel Organization of Legal Metrology, as amended.

Legal metrology, as broadly defined, relates to the compatibility of standards of meesurement and the legislation or regulations which may affect them.

The International Organizetion of Legel Metrology, established in 1955, is concerned primarily with standards for instruments and measurement techniques involved in the legal determination of quantity ard quality. Presently, many of its 36 member nations and eight corresponding members are European.

The Organization's tasks fall generally into two groups:

to serve es a center for documentation and information; to foster close working relations with naticanl weights and measures services and other concerned organizetions; and to furnish advisory assistance to interested countries.

to deternine the general Frinciples of legal metrology; to recommend uniform international requirements for measurine instruments; and to work out model laws and repulations for consideration by member countries.

The Organization's recommendeticns are not binding but they gre eccepted by nost member nations -- many of which are also our major tradine fartners.

The United States has in the past been an interested cbserver in the Organization's work and I believe that accession to the Corvention hould now be cf ciear advantase to the inited States. As the worli's larcest tradire ration and as a world leace in the stanciards field, we would be better eble to assure a positive role in the

setting of international standerds for measuremerts and, in so doing, to expand our international trade.

I recomend that the Senate give favorable consideration to Inited States accession to this Convention, as amended.

Richard Nixon.

TAB 2

\author{
MEMBER STATES \\ OF THE INTERNATIONAL ORGANIZATION \\ OF LEGAL METROLOGY
}

(September 1972)

Republic of West Germany
United Arab Republic
Australia
Austria
Belgium
Bulgaria
Cameroun
Sri Lanka (Ceylon)
Cuba
Denmark
Dominican Republic
Spain
Finland
France
United Kingdom of Great Britain
and of Northern Ireland
Guinea
Hugnary
India
Indonesia

Iran

Israel

Italy

Japan

Lebanon

Morocco

Monaco

Norway

Low Countries

Poland

Rumania

Sweden

Switzerland

Czechoslovakia

Tunisia

U.S.S.R.

Venezuela

Yugoslavia

United States of America

\section{MEMBER CORRESPONDENTS}

Greece -- Jamaica -- Jordan -- Luxembourg -- NepaI - New Zealand -- Pakistan -- Turkey -- Arab Organization for Standardization and Metrology 

International Organization of Legal Metrology

(CTMIL)

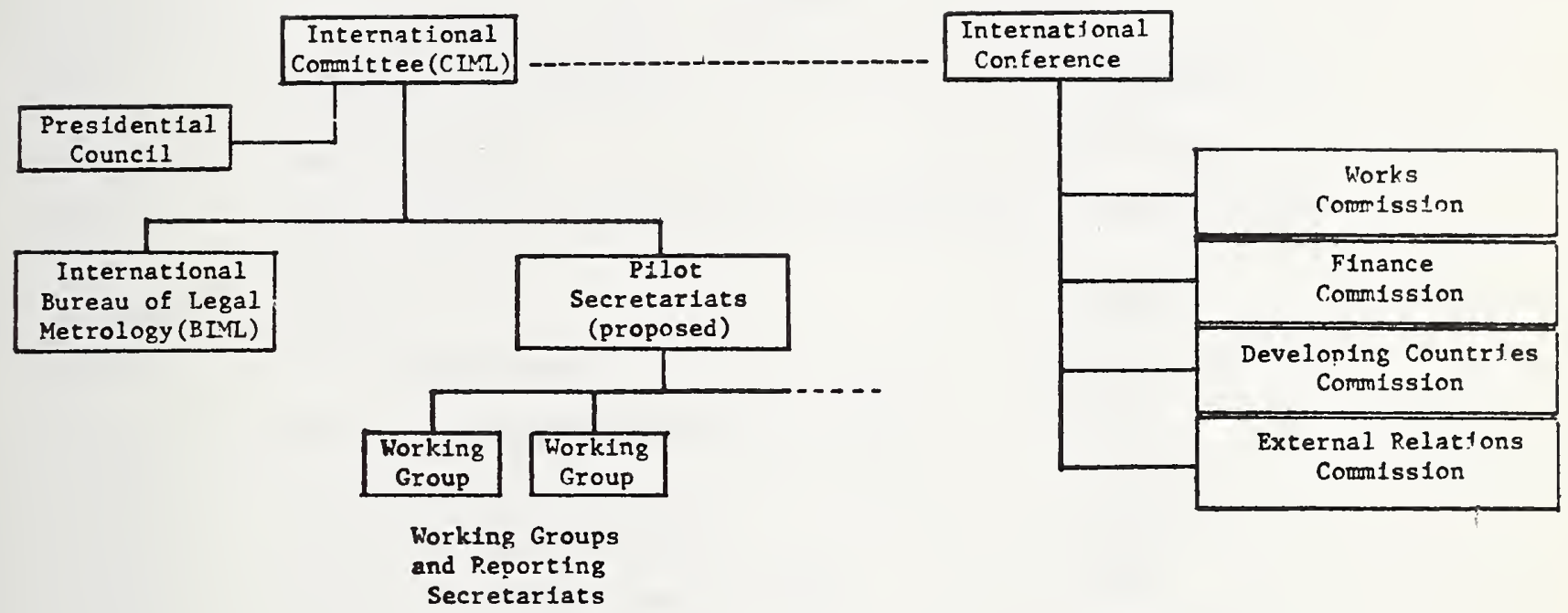

\section{Notes:}

1. U.S. Membersh1p in OML, October 22, 1972.

2. A. J. Van Male (Netherlands), Presldent, CIML.

3. W. E. Andrus, Jr, (NBS), U.S. representative to CDML.

4. M. Costamagna (France), Director, BIML.

5. B. Athane (France), Director Elect, BIML $(2 / 1 / 74)$. 
FOURTH I:TEENTTONAL CORFERENCE

OF LEGAT : ERROLOGY

LO:-2N, CCMOEET 1972

\section{FROJEZT FECOREEDATICHE}

Documents

$C_{4} \quad 1972$

Frofect

PR. 14

Polarimetric Saccharizeters

FR. 20

PR. 21

PR. 22

PR. 23

PR. 24

PR. 25

PR. 26

PR. 27

PR. 28

PR. 29

PR. 30

PR. 31

PR. 32

PR. 33

PR. 34

PR. 35

PR. 36

PR. 37

PR. 38

FR. 39

PR. 40

PR. 42
Service Measures

Auxiliary Devices for Meters - For Liquids Other Then Water

Taximeters

Tire Pressure Gauges

Classes of Precision Measuring Instruments

Verification Agent's Standard Metre Measure

Verification Agent's Standard Weights

Gas Meters, Deformable Wall

Alcoholometry

Technical Regulations for fion-Automatic Weighing Machines

Conventional Value of Results of Weight in Air

Gas Meters, Rotating Piston and Turbine

Vocabulary for Legal Metrology

Verification of Indenters of Hardness Testing Machines

Verification of Hardness Testing Machines: Brinell System.

Vickers System

Rockwell B and C

Recomendation No. 1, Cylindrical Weights $18-10_{k g}$

Recommendation No. 2, Rectangular Bar Weights
$5 \mathrm{~kg}-50 \mathrm{~kg}$

Length Measurements with a Flat-Edged Instrument

Medical Seringes
Precision Weights of Clesses $E_{1}, E_{2}, F_{1}, M_{1}$
Federal Republic of Germany

Switzerland

Germany \& France

Germany

USSR

USSR

India

Belgium

India

Netherlands

France

Germany \& France

BIML

\section{Germany}

Poland

Austria

Austria

Austria

Austria

Belgium

Belgium

USSR

Austria 
- 
1. Cylindrical weights from $1 \mathrm{gram}$ to $10 \mathrm{kflo-}$ grams (of medium class of accuracy).

2. Rectangular weights fror. 5 to 50 kilogrammes (of medium class of accuracy).

3. Netrological regulation of weighing instruments with nonautomatic operation and commentaries concerning the determination of the errors on weighing instruments with discontinuous indication or impression.

4. One mark glass measurine flasks.

5. Meters for liquids (other than water) with measuring chambers.

6. General prescriptions for volumetric gas meters.

7. Clinical thermometers (mercury, in glass, with maximum device).

8. Working standard mettod for the verification of instruments for measuring the degree of humidity of cereal grains.

9. Verification and calibration of hardness reference blocks Brinell.

10. Verification and calibration of hardness reference blocks Vickers.

11. Verification and calibration of hardness reference blocks Rockwell B.

12. Verification and calibration of hardness reference blocks Rockwell C.

13. Correspondence symbol.

14. Polarimetric saccharimeters.

15. Instruments for measuring the mass per hectolitre of cereals.

16. Pressure gauges for instruments measuring arterial blood pressure.

17. Indicating pressure gauges, combined pressure and vacuum gauges and vacuum gauges, with pressure-responsive elements givine direct indications by means of a pointer and graduated scale (working equipment category).

18. Optical pyrometers with disappearing filaments.

19. Recording pressure gauges, combined pressure and vacuum gauges, ard vaculm gauges, with pressure-responsive elements and recording directly by means of stylus and diagram (working 

$\underline{T A B} 5$

RENARKS NADE EY DR. LAWRENCE $\because$ KUEYNER, ACTING DIPECMOR OF THE WAIIONAL

BUPEAU OF STAITALDS AND HEAL OF THE U.S. DELEGATION TO TEZ FOURTE

INTERNATIONLL CCITFEEENCE CF THE INTERNATIOI:AL ORGANIZATION OF LEGAL METROLOGY, ON THE SUBJECT OF LOIYG-KANGE WORK POLICY IN OIML

Mr. Chairman,

I should like to take this opportunity to offer several comments on the long-range policy for OIML.

First, however, I would like to point out that U.S. accession to the 1955 Convention establishing OIML reflects the recognition in the U.S. of the importance of OIML and the significance of its accomplishments. Thus, my remarks should not be interpreted as wishing to decrease either of these. Rather, my remarks are made necessary by the very importance of the work of OIML and the great impact of its work on the affairs of nations and trade arong them.

It is the U.S. view that the main purpose of OIML, expressed in simple terms, is to assure that those regulations of its member governments which involve metrological matters should be in harmony. I would urge the Conference to recognize that countries vary widely in the extent to which metrological matters are the concern of government, particularly, as one considers fields of metrology far removed from traditional weights and measures. Thus, since governments which belong to OIMI are "morally obliged" to use its recommendations, it is essential that OIML consider only those areas of metrology for which its member governments can, in fact, accept the moral obligation. If OIML adopts recommendations which its member governments cannot accept as morally obligatory because they deal with subjects that are not governmental matters in those ccuntries, then I am afraid that the concept of "roral oblication" will become seriously eroded and compronised over a period of time.

On the matter of metrological standards being based on performance as opposed to those based on design, the U.S. recognizes the wide variance in the technolosical development of metrology amone the OIML member states. In those countries in which metrological technology is less vell developed, desien specifications are most useful -- and perhaps the only practical aprroach. But such specificaticns, applied in those courtries wose metrolocical technology is more highily develcped, can be undesirably restrictive and inhibitir.s. One possible avenue of approach, whick is apparently already being taken by some OIMI workinf groups and if so is to be encourased, is to draft recomendations, the first secticns of which cesl with the subject matter in terms of the desire cerformance and subsequent sections of which Frovide examples of desig:. speciticaticns which will meet the prescribed performance.

This leads to my firal point. Writing the best possitle performance recormendations or design recommendations is, as we $31 \mathrm{know}$, a difficult and time-consuming matter. Thus, it is incumbent on OIMI working groups to draw as heavily as possible on all available services of technical expertise and to draw as heavily as possible on what has already been done or is being done, in other standardization bodies. Here I refer particularly to the efforts of the major international standardization bodies such as ISO and IEC. But this shovid not be a one-way street. I would similarly encourage those bodies when undertaking work in a field which may be of concern to legal metrology to do so only in close consultation with OIML experts. There must not be a competition but a true couperation and coordination. 
• 


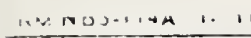

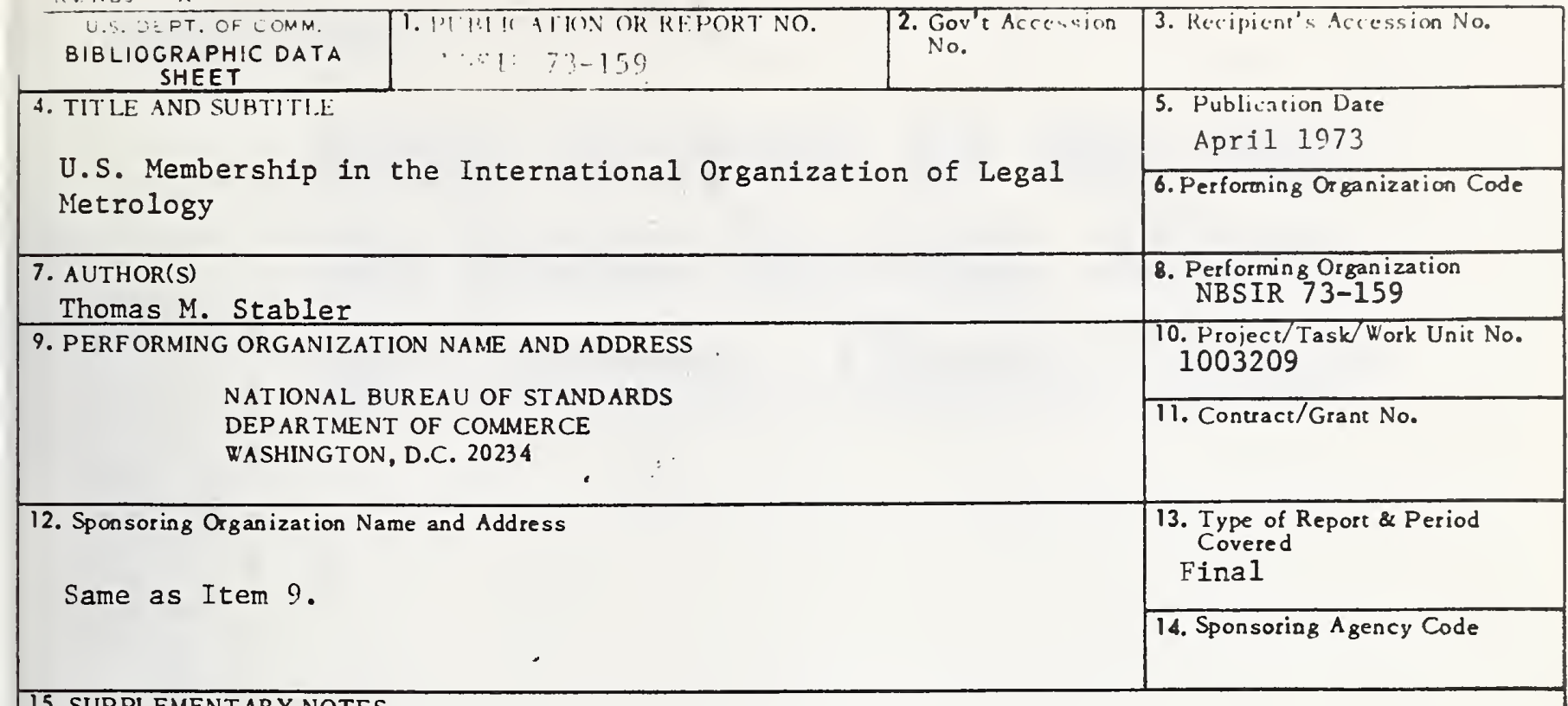

15. SUP PLEMENT ARY NOTES

16. ABSTRACT (A 200-word or less factual summary of most significant information. If document includes a significant bibliography or literature survey, mention it here.)

The International Organization of Legal Metrology (OIML) was formed in 1955 to promote intergovernmental cooperation in the field of weights and measures. In addition to its responsibilities as the center of documentation and information exchange in legal metrology, the OIML recommends uniform international requirements for measuring instruments and drafts model laws and regulations for consideration by the member states.

In October 1972 the United States became the 38 th member nation of OIML, with NBS being assigned general responsibility for the development of U.S. positions for technical matters arising in the organization.

The benefits to the U.S. of participation in OIML are: (1) To improve opportunities for exporting measuring instruments, (2) To obtain better information regarding measurement techniques in the field, (3) To influence internationally adopted measurement technique so U.S. procedures will not be at a disadvantage, (4) To insure that the U.S. can influence the adoption by developing countries of model laws and uniform procedures, (5) To facilitate the development of an international standards program for the U.S. in legal metrology.

The U.S. Delegation participated in the International Conference of oIM held in London, October 23-28, 1972.

17. KEY WORDS (Alphabetical order, separated by semicolons) Developing countries; International Bureau (BIMI); International Committee (CIML); International Conference; International Organization of Legal Metrology; International Recommendations; legal metrology; OIML

\begin{tabular}{|c|c|c|}
\hline $\begin{array}{l}\text { 18. AVAILABILITY STATEMENT } \\
\qquad \mathrm{X} \text { UNLIMIT ED. }\end{array}$ & $\begin{array}{l}\text { 19. SECURITY CLASS } \\
\text { (THIS REPORT) } \\
\text { UNCL ASSIFIED }\end{array}$ & 21. NO. OF PAGES \\
\hline $\begin{array}{l}\square \text { FOR OFFICIAL DISTRIBUTION. DO NOT RELEASE } \\
\text { TONTIS. }\end{array}$ & $\begin{array}{l}\text { 20. SECURITY CLASS } \\
\text { (THIS PAGE) } \\
\text { UNCL ASSIFIED }\end{array}$ & 22. Price \\
\hline
\end{tabular}


